\title{
Educational Modernization Drives the Development of Culture and Innovation
}

\author{
Roslinda Murad, Supyan Hussin, Rizal Yusof
}

To Link this Article: http://dx.doi.org/10.6007/IJARBSS/v10-i11/8054

DOI:10.6007/IJARBSS/v10-i11/8054

Received: 13 September 2020, Revised: 18 October 2020, Accepted: 17 November 2020

Published Online: 29 November 2020

In-Text Citation: (Murad et al., 2020)

To Cite this Article: Murad, R., Hussin, S., \& Yusof, R. (2020). Educational Modernization Drives the Development of Culture and Innovation. International Journal of Academic Research in Business and Social Sciences, 10(11), 1016-1031.

\section{Copyright: @ 2020 The Author(s)}

Published by Human Resource Management Academic Research Society (www.hrmars.com)

This article is published under the Creative Commons Attribution (CC BY 4.0) license. Anyone may reproduce, distribute, translate and create derivative works of this article (for both commercial and non-commercial purposes), subject to full attribution to the original publication and authors. The full terms of this license may be seen at: http://creativecommons.org/licences/by/4.0/legalcode

Vol. 10, No. 11, 2020, Pg. 1016 - 1031

Full Terms \& Conditions of access and use can be found at http://hrmars.com/index.php/pages/detail/publication-ethics 


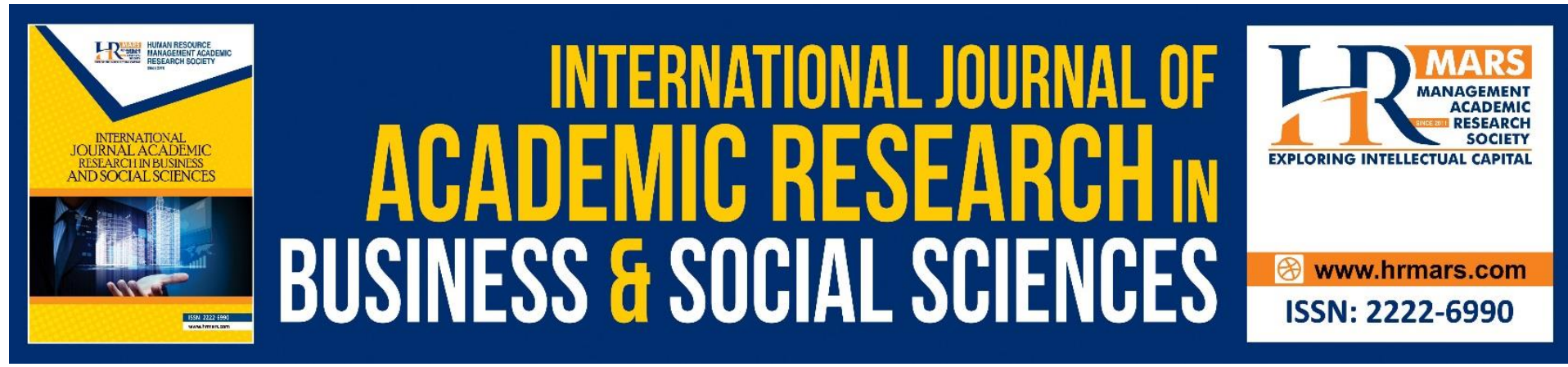

\title{
Educational Modernization Drives the Development of Culture and Innovation
}

\author{
Roslinda Murad ${ }^{1}$, Supyan Hussin², Rizal Yusof ${ }^{3}$ \\ Kolej Universiti Poly-Tech MARA Kuala Lumpur, Malaysia, Universiti Kebangsaan \\ Malaysia(UKM), Malaysia \\ Email: roslinda@kuptm.edu.my, supyan@ukm.edu.my,army@ukm.edu.my
}

\begin{abstract}
This conceptual paper studies the educational modernization drives the development of culture and innovation. Studies have shown that education helps to improve the potential of individuals while preserving the local culture. The Industrial Revolution 4.0 was a new era in the use of advanced technology. Humans are cultural beings, essentially the creators of culture itself. Culture develops alongside the potential of human beings to develop as cultural creators. The application of the M-learning approach takes into account the weaknesses of traditional learning systems. As such, recognizing advances in information and communication technologies, modernizing education can foster the development of local culture will help educators and students benefit from its visualization and content. The entire study will use quantitative and qualitative methodologies to evaluate results through questionnaires and interviews with stakeholders in higher education institutions, while building the $M$-Reminders \& Notes mobile application, the ADDIE model is used according to the phase of analysis, design, development, implementation and evaluation. This article aims to discuss the conceptual framework and the proposed application M-Reminders \& Notes as an innovation project in the promotion of cultural development. The modernization of education has a profound effect on the development of local culture today and seeks information with technical assistance to bring out new changes in teaching and learning techniques.
\end{abstract}

Keywords: M-learning, Educational Modernization, Cultural Development, Innovation, Learning Technology.

\section{Introduction}

Education in Malaysia is now heading to the Industrial Revolution 4.0 era using virtual technology and advanced equipment. The modernization of today's education has a major impact on the development of regional cultures that demand the availability of information with technical assistance to bring new changes to teaching and learning techniques. Education works to increase the potential of individuals while maintaining the local culture. Human being as a cultural creature, essentially the creator of culture itself. Culture is evolving in parallel with the enhancement of human potential as a creator of culture. 
Products such as iPhone, Android, Blackberry, Twitter, Facebook, YouTube, and Google are due to the emergence of innovative ideas in Western Europe. According to Razli Ahmad (2014), this invention has changed the way people live today, making human life more challenging, fun and competitive. In fact, Modernization of education has made some countries more prominent like Korea, Finland and other developed countries. Faced with the situation, Malaysia also needs to look forward to turning education in new directions, especially among the new generation, to promote the development of the culture of our country.

According to Klaus Schwab (2017), the industrial revolution 4.0 can be illustrated by the emergence of intelligent robots, driverless vehicles, supercomputers and the development of neurotechnologies to facilitate human life using robots that are the best friends in the management of activities and daily tasks. Believe it or not, one day the food order that we place by phone will be delivered by drone to the front door. In addition, all household chores, such as cleaning the dishes, carving the ground, feeding the animal and turning off the lights, must press the buttons on their smartphone without having to clean the house. To get to work, we do not have to worry about driving on congested roads. Everything will be done by simply pressing a key, passengers will be able to continue sleeping in their car and all driving devices will be fully satellite controlled to their destination. This situation may seem strange, but it will gradually become a common form of the future and all human affairs will be shared with specially designed robots to optimize needs and comfort. Although these technologies are still in the global testing phase, many applications used have been appreciated. For example, the use of navigation applications such as Waze or Google Maps, which provides drivers with travel and travel information, is one of the first examples of a global introduction called Internet of Things (IOT).

However Ab. Halim Tamuri et al. (2017) argue that modern education is not just about creating good citizens, but more about the citizens of the world with skills, knowledge and motivation to tackle humanitarian and environmental issues. It says. Especially in the context of Malaysian, the development of cultural development brings a positive attitude, and in order to eliminate racial prejudice and the flow of people in order to respect ethnic, racial and cultural differences. It is about creating solidarity between various races and ethnic groups in Malaysia. Cultural value should be understood as a series of values closely related to the social system of society.

Meanwhile Lamsah \& Chear (2017), the modernization of today's education is global, often related to the achievement of learning outcomes and the marketability of graduates. Advances in communication and information technology (ICT) have more closely connected world communities and organizations with one another in a more borderless world community. Modern learning also emphasizes the rapid development and progress after mobile technology has been applied to Malaysian educational systems, but motivates students and by using mobile learning technology or m-learning gave an opportunity to study thoroughly Analisa Hamdan et al. (2013). The use of modern equipment, such as mobile learning technology and modern life needs, has enabled the human mind and attitude to create new values in line with the strength of technology influence and socio-cultural life. In this regard, education is a tool of community social strength to develop a system for instilling members of society related to changing demands of time. 


\section{Research Background}

The modernization of education to the era of revolution industry 4.0 requires a new surge and paradigm for the diversity of cultures and the complexity of the challenges to be faced. In fact, globalization has opened up all spaces and opportunities for students to accept any form of influence whether positive or negative. In this century, information boom has made Malaysia dramatic progress in various aspects of life. A positive approach and conducive environment with students must be created so that they can receive information, views and ideas through more effective teaching and learning processes.

Apart from that (Zahiah \& Abdul Razaq, 2010), it was identified as a challenge for educators to link the gap between awareness and knowledge between instructors and students in teaching and learning. It cannot be denied that infinite global factors and the rapid rise of globalization have a profound effect on the development of Malaysian citizens and the effectiveness of the education system. Long exposure to mass media and social influences adversely affects students' moral value. The presence of various TV channels, radios, and millions of web pages is a matter of youth education, especially Muslim youth. It is important to focus not only on the infrastructure and classroom layout but also on the effectiveness of this modernized education. The final determinant of success is student-centred teaching and learning activities. The role of the instructor is becoming increasingly difficult as it should be an effective facilitator for students in and outside the classroom. Industrial Revolution 4.0 era, you need to prepare all levels of education for education and learning. That is because they are the enforcement mechanism for all developed policies and curriculums.

The era of the Industrial Revolution 4.0 accesses and browses ever-growing new media. According to statistics announced in 2015 (Malaysia Social Media Statistic 2014, 2016), there are 10.4 million active Facebook users, 3.5 million twitter users, and 5.6 million people who will be Instagram users. Data also show that 21.9 million (73\%) of Malaysians use the WhatsApp ratio, which has the third highest population in the world. In fact, according to the data, 19.2 million (64\%) of the population are Internet users, and they use 2.8 hours a day to access social websites. Apart from the survey results, it also shows that 16.5 million (55\%) Malaysians are active users of social media. Even consumption levels are expected to increase, in particular Facebook is expected in 2019, and Malaysia is expected to have 13.2 Facebook users (Malaysia number of Facebook users, 2016).

As all teens and students use smartphones in their daily activities, it is good that the new era educational is focused on mobile learning technology. Local possibilities and development strategies based on what our society needs are not what we need. Because, in many cases, what is required is because it is completely different from what we need. Hence, the cultural developments in new era educational as an example is highlighted in the form of Upin and Ipin animations that bring in the art of 'silat cekak', 'galah panjang' game, village environment, science teaching and sociocultural society.

However, (Lamsah \& Chear, 2017) explains the important relationship between the development of adolescent social psychology and the exposure of mass media and social media. In the Malaysian context, social media use among Malaysians is at the highest level in the world and is expected to continue to grow. The ease of the Internet network and the sale of various inexpensive and easy-to-use wireless mobile devices are increasing the use of social media among the domestic community.

Ab. Halim Tamuri (2017) encourages us to work together to look at the Japanese people who represent them in the global community. Look at them to stick to their cultural roots wherever they are. They are examples of countries successfully modernized based on 
regional possibilities. With regard to incoming foreign influences, they absorb and overcome their culture rather than swallowing them. Local culture is an integral part of sustainability and can be used to contribute to the positive development of a formal and informal education world. The science of wisdom is also dynamic and can be used in different approaches and different educational stages.

\section{Problem}

In recent years, the problems in education system arose, especially in Higher Learning Institution in Malaysia. One of the problems is a technique or approach being implemented in a common classroom environment which student is quite boring during learning. Coming face to face classroom have somehow to change in virtual environment due to the fact that teaching and learning can be dynamically transformed into the technological system.

Norliza (2013) identified the weaknesses of E-Learning governance and the use of the latest teaching aids as well as the lack of guidance on the use of E-Learning is one of the problems faced in the field of education. Adapting as a student is very difficult because too many assignments are given can cause students to miss the deadline to submit assignments. Apart from that, Supyan (2016) identified that learning in the lecture room gives a lot of impact especially in the problem of space usage, electricity usage for printing, energy consumption and high cost with the use of paper. The same goes for some students who go to class deliberately not carrying or forgetting to bring a notebook.

According to Zanaton (2017) the weaknesses of the traditional learning system that invite the boredom of students attending lectures, attendance and student involvement are among the major problems in the classroom. In addition, students who are too busy with assignments, part-time work and personal matters will affect their learning schedule due to inefficient time management. M. Radzi (2017) stated that through case studies in Malaysia, Universiti Terbuka Malaysia (OUM) is a pilot university that implements mobile learning in a large scale smart environment in 2004 and followed by Universiti Sains Malaysia (USM) in 2010 In its project, OUM has used SMS to deliver notices, reminders and motivational messages to its student. Apart from OUM and USM, little is known about any other project or study involving other institutions of higher learning that implement $\mathrm{m}$-Learning on such a scale. 
Table 1. Previous Study by Theme

\begin{tabular}{|c|c|c|c|c|c|}
\hline No & Researcher & $\begin{array}{l}\text { M- } \\
\text { learning }\end{array}$ & $\begin{array}{l}\text { Current } \\
\text { Practic } \\
\text { e }\end{array}$ & $\begin{array}{l}\text { Benefit } \\
\text { s }\end{array}$ & $\begin{array}{l}\text { Challenge } \\
\text { s }\end{array}$ \\
\hline 1 & $\begin{array}{l}\text { (Flavius \& Ferdi, 2011) } \\
\text { (Osman, Bachok, Bakri, \& Harun, } \\
\text { 2014) } \\
\text { (Nascimento, 2017) }\end{array}$ & & & & \\
\hline 2 & (Yavari, 2016) & & & & \\
\hline 3 & $\begin{array}{l}\text { (Rahman, 2016) } \\
\text { (Bhamare, Erbad, Jain, \& Samaka, } \\
\text { 2017) }\end{array}$ & & & & \\
\hline 4 & $\begin{array}{l}\text { (Ye Conghuan, 2011) } \\
\text { (Krish, Hussin, Manap, \& Amir, } \\
\text { 2012) } \\
\text { (Badusah \& Amin, 2013) } \\
\text { (J. A. Lee, Kim, \& Chung, 2013) } \\
\text { (M. Lee \& Son, 2013) } \\
\text { (Salah, Lela, \& Al-zubaidy, 2014) } \\
\text { (Sung, Chang, \& Liu, 2016) } \\
\text { (Kiat, Ali, Halim, \& Ibrahim, 2016) } \\
\text { (Giuliani et al., 2016) } \\
\text { (Syazwani Ismail, Harun, Aman } \\
\text { Zahiri Megat Zakaria, \& Md Salleh, } \\
\text { n.d.) } \\
\text { (Ramírez-Donoso, } \\
\text { Riethmuller, Pérez-Sanagustín, \& } \\
\text { Neyem, n.d.) } \\
\text { (Jiugen, Rongrong, \& Ruonan, n.d.) } \\
\text { (Zanaton, 2017) } \\
\text { (Lamsah \& Chear, 2017) } \\
\text { (Noriyani, 2017) } \\
\text { (Shen et al., 2017) }\end{array}$ & & & & \\
\hline 5 & $\begin{array}{l}\text { Norliza (2013) } \\
\text { (Analisa Hamdan et al., 2013) } \\
\text { (Khalid \& Yusoff, 2016) } \\
\text { (Cheng, Kung, Li, \& Sun, 2016) } \\
\text { (Fuad \& Deb, n.d.) } \\
\text { (Mohd Zainudin, n.d.) } \\
\text { (Normah Husin, Nor Azhan Norul } \\
\text { 'Azmi, 2017) }\end{array}$ & & & & \\
\hline 6 & $\begin{array}{l}\text { (Al-Hunaiyyan, Alhajri, } \quad \& \quad \text { Al- } \\
\text { Sharhan, 2016) }\end{array}$ & & & & \\
\hline 7 & $\begin{array}{l}\text { (Asabere, 2013) } \\
\text { (Mehdipour \& Zerehkafi, 2013) }\end{array}$ & & & & \\
\hline
\end{tabular}




\begin{tabular}{|l|l|l|l|l|}
\hline 8 & $\begin{array}{l}\text { (Pholotho \& Mtsweni, 2016) } \\
\text { (Zbick, n.d.) Shuib, Ghani, } \\
\text { (Elaish, } \\
\text { Yadegaridehkordi, \& Alaa, 2017) }\end{array}$ & & & \\
\hline Research & $\begin{array}{l}\text { Educational Modernization Drives } \\
\text { the Development of Culture and } \\
\text { Innovation }\end{array}$ & & \\
\hline
\end{tabular}

Table 1 illustrates the previous study with four main themes namely $\mathrm{m}$-learning, current practice, benefits and challenges. According to (Ye Conghuan, 2011b) managing and supplying educational resources to consumer applications is a major challenge. Meanwhile Analisa Hamdan et al. (2013) identified the concept of the lecture room should be translated into a new environment. Therefore Suhazimah (2016)stated that the MAMPU is implementing initiatives to enhance service delivery by prioritizing the civilians. MAMPU also try transform of the public service delivery system towards the Digital Government. Syazwani Ismail et al. (n.d.) said Teaching and learning resources are an important factor for the effectiveness of active learning. However Ramírez-Donoso et al. (2017) stated that although the e-learning system has a strong platform and supports and stores high data capacity but is limited in the development of certain class activities only. In particular, existing platforms lack equipment to facilitate group work. In addition Lamsah \& Chear (2017) from Universiti Selangor stated education is global and related to the availability of graduates. ICT makes the world borderless and Z.Ibrahim (n.d.) from MAMPU said that Service delivery mechanisms for the education sector are still lower than transport, fishery, agriculture, security or smart city sector. The gap analysis as a result of previous studies, and so far is still lacking in special studies on current practices, benefits and challenges in the implementation of m-learning.

Basically, this study would like to consider what are the essential elements needed to build educational modernization. Next, how modernization of education contributed to the cultural development that led to the industrial revolution 4.0. Apart from that, what are the specific limitations for the implementation process related to resources, such as technical aspects, support and assistance, time, human resources, technical skills, financial factors, assistance factors in the context of mobile services. Then, what are the views and experiences of using mobile applications in communication, education and learning. This study also focuses on leveraging the integration of social applications with the development of mobile applications used as an alternative to improve the quality of education. Higher education institutions should be prepared for change, especially in terms of educational approaches to attract students and be accepted by society.

\section{Objectives}

The objective of this study is to review current practices for implementing $\mathrm{m}$-learning based on mobile apps and self-learning, exploring the benefits of m-learning to improve the learning process and look at cultural developments in modernization of education and identifying challenges that affect users in implementing $m$-Learning. However, the objective of this paper is to introduce the conceptual framework as well as mobile app suggestions entitled M-Reminders \& Notes as an innovation project. 


\section{Research Methodology}

The research methodology which comprise four phases including the Design Conceptual Study, Development of mobile application, Data collection and provide Quantitative empirical study. This section explains the method of theoretical study to establish the research area and scope, identifying constructs or attributes for questionnaire design, data collection and analysis.

As for the data collection method, through purposive sampling, questionnaires will be distributed to 400 respondents at higher institution. The data collection in the empirical and exploratory study will be analysed using appropriate statistical methods. Results of the analysis contributed to the achievement the stated objectives. Evidence, findings and observations during the Design Conceptual Study, Development of mobile application, Data collection, and Quantitative empirical study were used as the basis for achieving the research objective to improvise modernization of education in cultural development lead to industrial revolution 4.0 .

Table 2. Research Methodology Approach.

\begin{tabular}{|c|c|c|}
\hline Input & Research Approach (process) & Results (Output) \\
\hline $\begin{array}{l}\text { Articles, } \\
\text { Books, } \\
\text { Journals, } \\
\text { Conference } \\
\text { Proceeding, } \\
\text { Magazine, } \\
\text { News, } \\
\text { Online Database } \\
\text { Journal, Standards, } \\
\text { ISO Guidelines, } \\
\text { Research Articles. }\end{array}$ & $\begin{array}{l}\text { - } \text { Review related areas } \\
\text { - Access online journal } \\
\text { databases } \\
\text { - Identify issues in the } \\
\text { knowledge research areas } \\
\text { - Propose mobile apps as } \\
\text { modernization of education. } \\
\text { - Design and distribute the } \\
\text { questionnaire } \\
\text { respondents to } \\
\text { - Study and review the current } \\
\text { quantitative data and } \\
\text { qualitative approach will be } \\
\text { applied to cross-validate } \\
\text { findings (interview } \\
\text { technique) }\end{array}$ & $\begin{array}{l}\text { - Literature review summary } \\
\text { - Distribute the questionnaire } \\
\text { to } 400 \text { respondents } \\
\text { (students, instructors and } \\
\text { administrators) } \\
\text { - Provide statistical analysis } \\
\text { based on data collection } \\
\text { (from questionnaire) }\end{array}$ \\
\hline
\end{tabular}

Table 2 shows the research methodology approach which contain plan for conducting research. Sociologists draw on a variety of both qualitative and quantitative research methods, including distribute questionnaires, survey research, participant interviews, and secondary data. Quantitative methods aim to classify features, count them, and create statistical models to test hypotheses and objective. Qualitative methods aim for a complete, detailed description including the context of events and circumstances.

For many years now, educators and instructional designers alike have used the ADDIE Instructional Design (ID) method as a framework in designing and developing educational and training programs. "ADDIE" stands for Analyse, Design, Develop, Implement, and Evaluate. The innovation project also used ADDIE model as framework in designing and developing MReminder \& Notes App. 


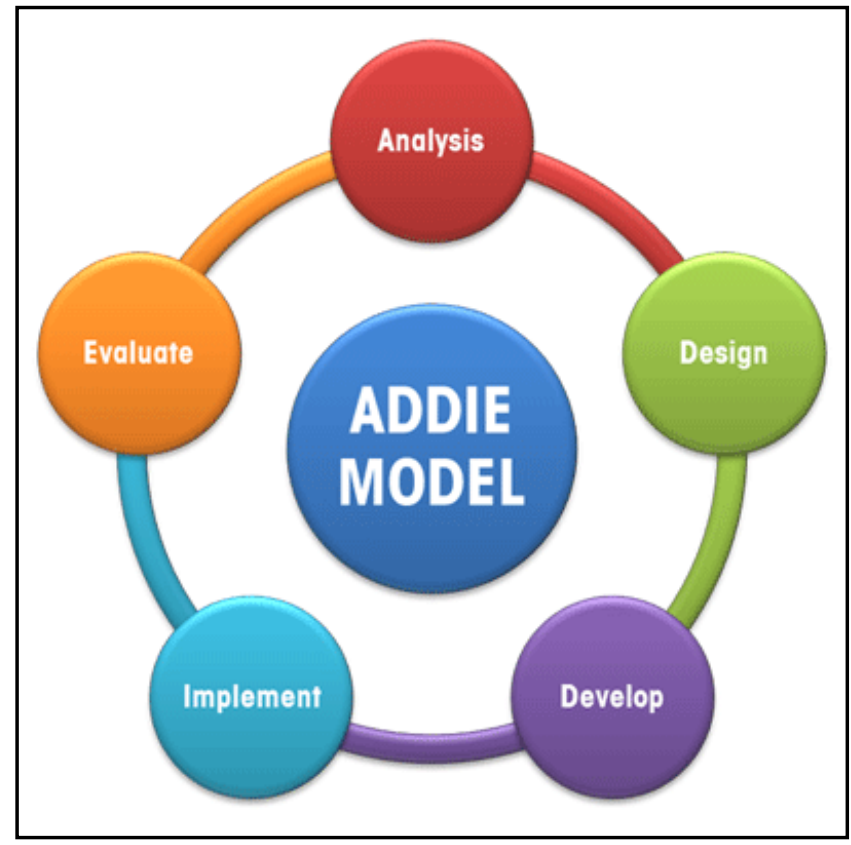

Figure 1: ADDIE Model

Figure 1 shows the generic term for the five-phase instructional design model consisting of Analysis, Design, Development, Implementation, and Evaluation. Each step has an outcome that feeds into the next step in the sequence.

The five phases of ADDIE are as follows:

\section{- Analysis}

During analysis, the designer identifies the learning problem, the goals and objectives, the audience's needs, existing knowledge, and any other relevant characteristics. Analysis also considers the learning environment, any constraints, the delivery options, and the timeline for the project.

\section{- Design}

A systematic process of specifying learning objectives. Detailed storyboards and prototypes are often made, and the look and feel, graphic design, user-interface and content is determined here.

\section{- Development}

The actual creation (production) of the content and learning materials based on the Design phase.

\section{- Implementation}

During implementation, the plan is put into action and a procedure for training the learner and teacher is developed. Materials are delivered or distributed to the student group. After delivery, the effectiveness of the training materials is evaluated.

\section{- Evaluation}

This phase consists of (1) formative and (2) summative evaluation. Formative evaluation is present in each stage of the ADDIE process. Summative evaluation consists of tests designed for criterion-related referenced items and providing opportunities for feedback from the users. Revisions are made as necessary.

\section{Proposed Conceptual Framework}

Through the problems of this study, the conceptual framework proposal has been designed to help solve it. 


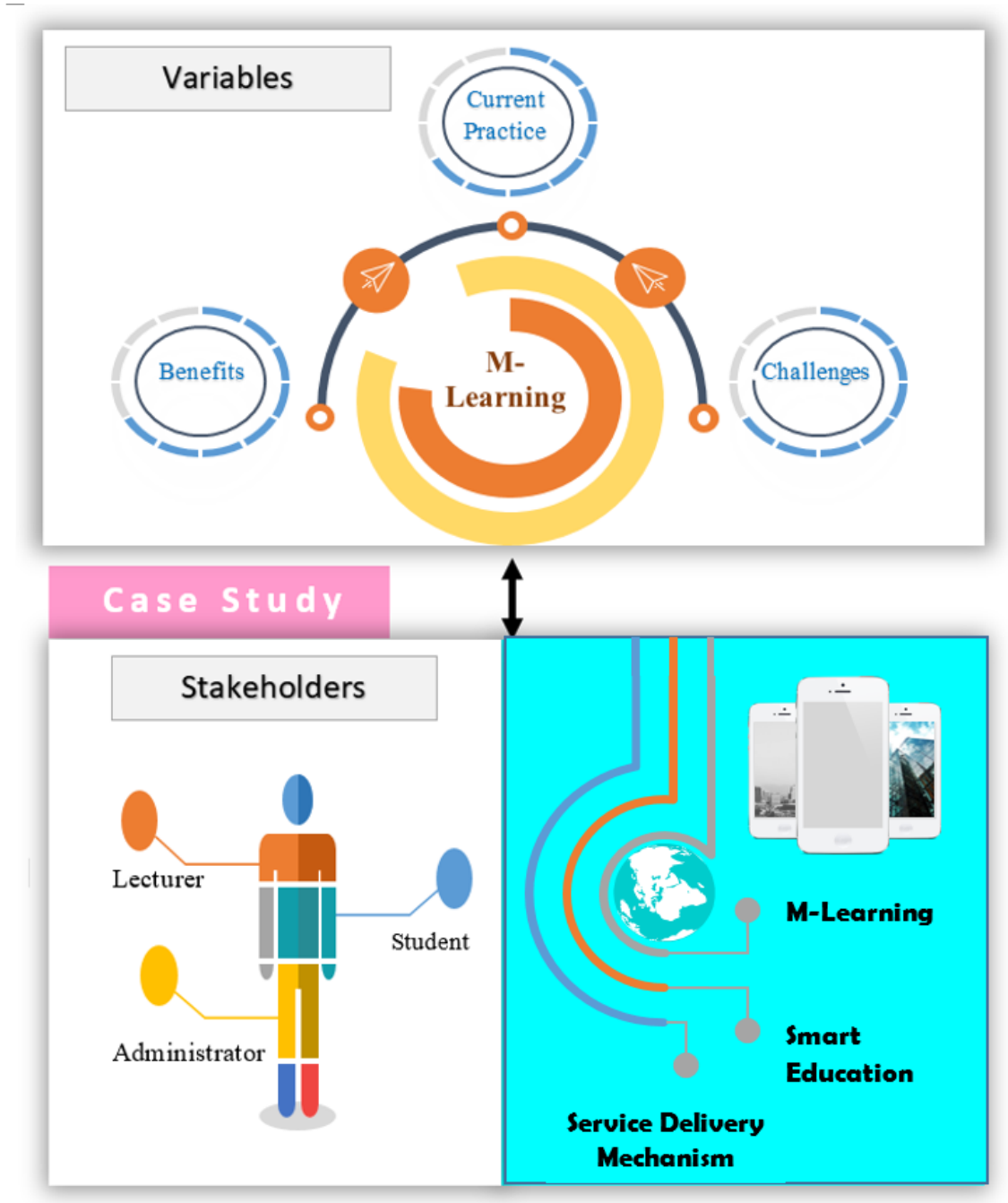

Figure 2: Conceptual Framework

Figure 2 shows the conceptual framework for this study which consists of variables and case study. There are some key elements in the study such as current practices, benefits and challenges as indirect variables while direct variables are $m$-Learning. Current practice variables are mediators between benefit variables and challenges. A case study will be conducted at the Kolej Universiti Poly-Tech MARA (KUPTM) and Kolej Poly-Tech MARA (KPTM) which involves lecturers, students and administrators as stakeholders who relate to each other in the context of service delivery mechanisms, smart education and M-Learning.

\section{Conceptual Framework Elements}

\section{- Current Practices}

To examine current practices on acceptance of $m$-Learning based on mobile apps and conduct self-study.

\section{- Benefits}

To explore the benefits of m-learning to improve the learning process in a smart education.

\section{- Challenges}

Reviewing challenges that affect users when implementing m-Learning.

\section{- M-Learning}

Mobile learning is a form of distance education that "learns through various contexts through social interaction and its content using personal electronic devices". As a distance education 
form, students use mobile learning technology at the right time and everywhere (Mehdipour \& Zerehkafi, 2013).

\section{- Lecturer}

Helps to transform traditional learning into local communities into blended learning that enables lecturers and supervisors to provide effective education, and help them access the mobile teaching world and evaluate their student performance continuously. In addition, lecturers can also disseminate important information to students by using their mobile devices anytime and anywhere quickly and easily.

\section{- Student}

Encourage students to activate their mobile devices; download mobile apps to support the $\mathrm{m}$-Learning process, and utilize them anytime and anywhere and have wireless networks available (Wi-Fi, 3G, 4G). In addition, it can help students to get the information they need especially in learning as in developed countries.

\section{- Administrator}

Spell the name of the institution by helping, managing and implementing $m$-Learning.

\section{- Service Delivery System}

The service delivery system is a set of principles, standards, policies and constraints that will be used to guide the design, development, use, operation and retirement of services provided by the service provider in order to offer a consistent service of a particular user community within the context of a particular business. The mechanism of delivery mechanisms is the context in which the capabilities of service providers are organized into service (W.M. Zawawi, 2015).

\section{- Smart Education}

The next generation of learning concepts, smart learning environment, and smart classroom concepts appear. Learning space is a new field of research aimed at promoting free, flexible learning and dealing with providing learning skills and appropriate learning methods (Zhuang et al., 2017).

\section{Proposed M-Reminders \& Notes App}

This innovative project is to build a mobile application that allows students and instructors to communicate and perform the teaching and learning process on a mobile basis. This app offers many new and more attractive designs so that it is more user friendly, and so that students have no problem in pursuing their studies at higher educational institutions. The notes in the app look more attractive, colourful and ease to read. Positively, this mobile app can improve student productivity and help students think innovatively and help in time management. All the features bundled with this mobile app work well, and this mobile app helps restore data so users do not have to worry about losing data.

There are novelties in educational practice that include in this mobile application which are:

- Comprehensive for reminder, scheduler and notes functions

- Keep informed about upcoming classes, reminds of quizzes, exams, events and unfinished assignments.

- The main features are timetable that shows schedule per day or week and notes to overview with text, photo and checklist format.

- Other helpful features such as automatically mute the phone during class and keep track of all related tasks. 


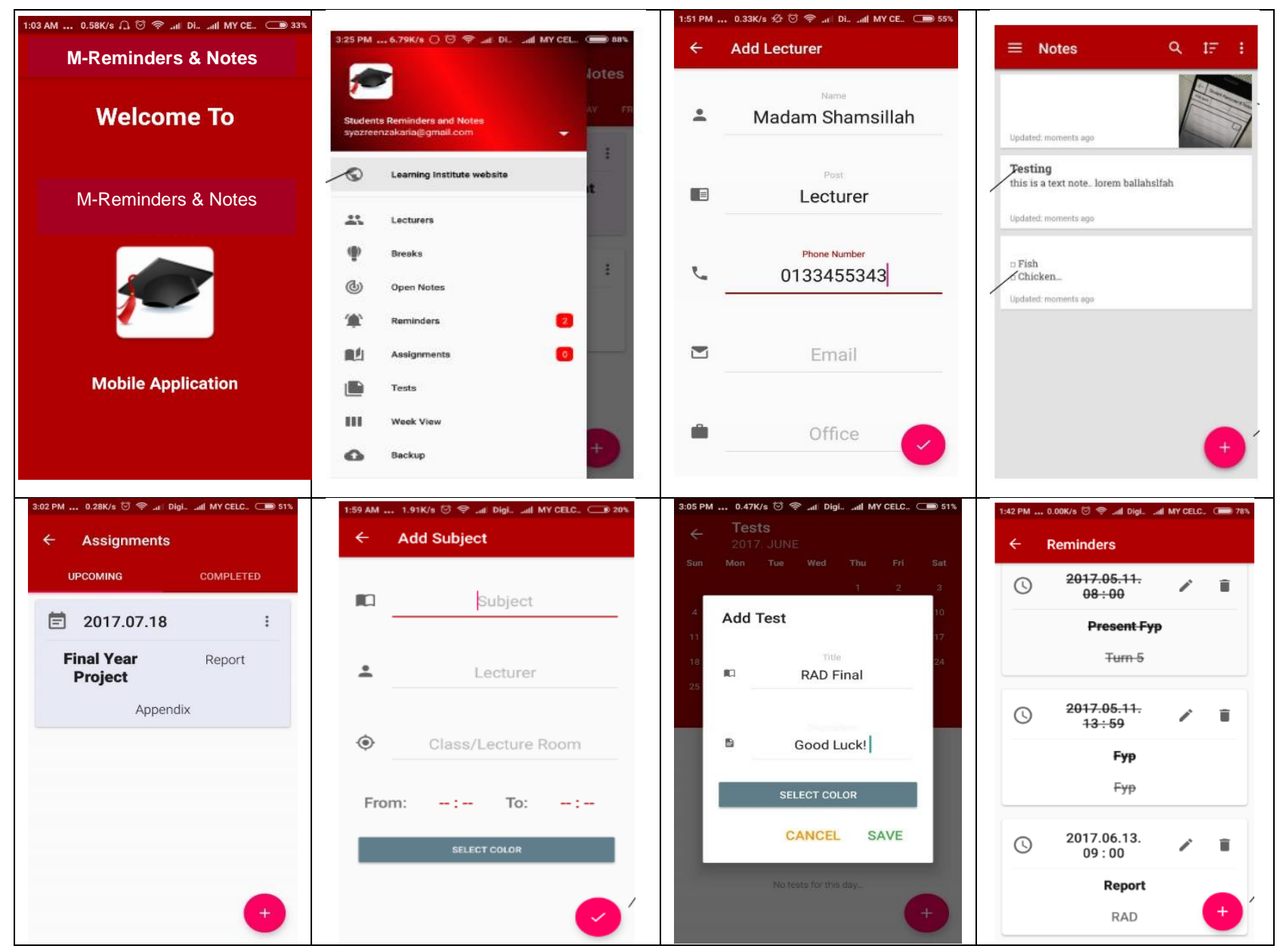

Figure 3: Interface of M-Reminders \& Notes App

Figure 2 illustrates some of the interfaces of the M-Reminders \& Notes App such as lecturer information, note display, assignment view, inserting subjects in a timetable, setting with entering test dates and alert or notification displays related to presentations, submission of reports and assignments. This mobile app gives some contributions to the latest practices as students can use the apps available on their smartphones instead of bringing textbooks or notebooks. Apart from that, it can also be a reminder of class schedules and train students to be more disciplined and help students with a steady daily schedule by managing, organizing and informing them. This application also contributes to green environment and efficient time management. The M-Reminders \& Notes app has also won five (5) international and national innovation awards, including one (1) gold and four (4) bronze medal.

\section{Conclusion}

Today's educational innovation has a significant impact on the development of local culture, which requires information and technical assistance to bring about new changes in teaching and learning techniques. Educational improves individual potential while preserving local culture. Humans are cultural beings who are essentially the creators of the culture itself. Culture is evolving alongside the growing potential of human beings as creators of culture. The rapid development of technology is meaningless unless it is balanced by social well-being, spiritual height, spiritual strength, and well-being. Through the use of the m-Learning approach and the development of the Application for Students naming M-Reminders \& Notes innovation project, it helps overcome the weaknesses of the traditional learning system. Thus, 
with the advancement of information and communication technologies, educational modernizations can strengthen the development of local culture and help educators and students take advantage of $\mathrm{m}$-Learning in terms of visualization and content.

\section{Contribution}

This study is very important in order to introduce the concept of mobile technology to users by using smartphones and downloading mobile applications (Mobile app). Users especially students and lecturers can access information anytime and anywhere they are. Therefore, this study contributes by enriching and helping to strengthen the construction and expansion of the corpus of knowledge through the field of information technology. Thus, to improve the quality of educational modernization, mobile applications are needed. Therefore, to meet this need, researchers have the opportunity to develop a mobile application known as $M$ Reminders \& Notes App. This application has been developed as a prototype and is in the testing phase to encourage cultural development and innovation.

\section{Acknowledgement}

The author would like to thank Prof. Dr. Supyan Hussin (Supervisor) ATMA, Universiti Kebangsaan Malaysia and management of Kolej University Poly-Tech MARA (KUPTM) that have helped in conducting this study.

\section{Corresponding Author}

Roslinda binti Murad

Kolej Universiti Poly-Tech MARA Kuala Lumpur, Malaysia.

Email: roslinda@kuptm.edu.my

\section{References}

\section{Book with one author}

Abraham, M. F. (2014). Contemporary Sociology: An Introduction to Concepts and Theory. Oxford University Press: OUP India

Schwab, K. (2017). The Fourth Industrial Revolution. Penguin Books Ltd: London, United Kingdom

\section{Journal Article}

Tamuri, Ab. H., N. H. H. (2017). Pendidikan Abad ke 21 Dalam Kepelbagaian Budaya : Cabaran dan Harapan Kolej Universiti Islam Antarabangsa Selangor ( KUIS ) Bahagian PendidikanAb. Halim Tamuri, Islam ,Ab. Halim Tamuri, Nur Hanani Hussin, (September).

Al-Hunaiyyan, A., Alhajri, R. A., \& Al-Sharhan, S. (2016). Perceptions and challenges of mobile learning in Kuwait. Journal of King Saud University - Computer and Information Sciences. https://doi.org/10.1016/j.jksuci.2016.12.001

Asabere, N. Y. (2013). Benefits and Challenges of Mobile Learning Implementation : Story of Developing Nations, 73(1), 23-27.

Badusah, J., \& Amin, M. (2013). Penggunaan M-Pembelajaran : Satu Inovasi dalam Pembelajaran Bahasa Melayu, (2010), 719-726.

Bhamare, D., Erbad, A., Jain, R., \& Samaka, M. (2017). Automated service delivery platform for C-RANs. 2017 2nd International Conference on Fog and Mobile Edge Computing, FMEC 2017, 219-224. https://doi.org/10.1109/FMEC.2017.7946434

Cheng, H., Kung, T., Li, C., \& Sun, Y. (2016). The Current State of Mobile Apps Development of 
Higher Education in Taiwan. ICACT Transactions on Advanced Communications Technology (TACT), 5(2), 780-786.

Elaish, M. M., Shuib, L., Ghani, N. A., Yadegaridehkordi, E., \& Alaa, M. (2017). Mobile learning for English Language Acquisition: Taxonomy, Challenges, and Recommendations. IEEE Access. https://doi.org/10.1109/ACCESS.2017.2749541

Flavius, P., \& Ferdi, P. (2011). Internet Service Delivery Models: Evolution and Current Issues. Cyber-Enabled Distributed Computing and Knowledge Discovery (CyberC), 2011 International Conference On, 146-153. https://doi.org/10.1109/CyberC.2011.33

Fuad, M. M., \& Deb, D. (n.d.). Cloud-Enabled Hybrid Architecture For In-Class Interactive Learning Using Mobile Device. https://doi.org/10.1109/MobileCloud.2017.15

Giuliani, F., Ottavi, M., Cardarilli, G. C., Re, M., Di Nunzio, L., Fazzolari, R., ... Zuliani, F. (2016). Design and characterization of a high-safety hardware/software module for the acquisition of Eurobalise telegrams. In 2016 IEEE International Symposium on Defect and Fault Tolerance in VLSI and Nanotechnology Systems, DFT 2016. https://doi.org/10.1109/DFT.2016.7684080

Jiugen, Y., Rongrong, K., \& Ruonan, X. (n.d.). Design and Development of SCORM-based Mobile Learning System. https://doi.org/10.1109/ITME.2016.121

Khalid, F., \& Yusoff, N. (2016). Tahap Kesediaan Pelajar Prasiswazah UKM dalam Penggunaan M-Pembelajaran, 2016(November).

Kiat, L. B., Ali, M. B., Halim, N. D. A., \& Ibrahim, H. B. (2016). Augmented Reality, Virtual Learning Environment and Mobile Learning in education: A comparison. In 2016 IEEE Conference on e-Learning, e-Management and e-Services (IC3e). https://doi.org/10.1109/IC3e.2016.8009034

Krish, P., Hussin, S., Manap, M. R., \& Amir, Z. (2012). Mobile learning readiness among Malaysian students at higher learning institutes. Asian Social Science, 8(12), 276-283. https://doi.org/10.5539/ass.v8n12p276

Lamsah, S., \& Chear, S. (2017). Pengajaran dan Pembelajaran Melalui Aplikasi Whatsapp dan Telegram di Universiti Swasta, 42(2).

Lee, J. A., Kim, T. H., \& Chung, J. H. (2013). Study on communication of characteristics smart learning from UX perspective. International Journal of Smart Home, 7(6), 59-72. https://doi.org/10.14257/ijsh.2013.7.6.06

Lee, M., \& Son, Y. (2013). A study of learning system for Smart Learning using BYOD. SERSC: Science \& Engineering Research Support SoCiety, 19, 106-111.

Mehdipour, Y., \& Zerehkafi, H. (2013). Mobile Learning for Education: Benefits and Challenges. International Journal of Computational ..., 3(6), 93-101 (251-259). https://doi.org/10.1080/87567555.2011.604802

Nascimento, D. M. (2017). Information flows in e-participation applications : Implications in government service-delivery in Brazil. International Conference on Information Society, i-Society 2016, (2), 51-52. https://doi.org/10.1109/i-Society.2016.7854172

Noriyani, D. (2017). Implikasi Google Apps dalam Pengajaran dan Pembelajaran Pelajar Pesisir UTHM, (July).

Norliza, R. (2013). Penggunaak Mobile Learning (M-Learning) untuk Tujuan Pembelajaran dalam Kalangan Pelajar Kejuruteraan UTHM. Thesis, (Jun), 1-75. Retrieved from http://plato.stanford.edu/archives/win2013/entries/phenomenology/

Osman, M. M., Bachok, S., Bakri, N. I. M., \& Harun, N. Z. (2014). Government Delivery System: Effectiveness of Local Authorities in Perak, Malaysia. Procedia - Social and Behavioral Sciences, 153, 452-462. https://doi.org/10.1016/j.sbspro.2014.10.079 
Pholotho, T., \& Mtsweni, J. (2016). Barriers to electronic access and delivery of educational information in resource constrained public schools: A case of Greater Tubatse Municipality. 2016 IST-Africa Conference, IST-Africa 2016, 1-9. https://doi.org/10.1109/ISTAFRICA.2016.7530626

Rahman, I. (2016). New Perspectives on Design and Delivery: the Context of Service Desk. https://doi.org/10.1177/0741713604268894

Ramírez-Donoso, L., Rojas-Riethmuller, J. S., Pérez-Sanagustín, M., \& Neyem, A. (n.d.). Enhancing Collaborative Learning in Higher Education Online Courses through a Mobile Game App.

Ahmad, R. H. H. (2014). Pembudayaan Kreativiti dan Inovasi Dalam Kalangan Pelajar Institusi Pengajian Tinggi : Kajian Ke Atas Pelajar Universiti Malaysia Perlis. Researchgate.Net, (September 2015), 0-11. Retrieved from https://www.researchgate.net/publication/263353345

Salah, A., Lela, M., \& Al-zubaidy, S. (2014). Smart Education Environment System, 4(4), 21-27. Shen, Y., Lee, J., Jeong, H., Jeong, J., Lee, E., \& Du, D. H. C. (2017). SAINT+: Self-Adaptive Interactive Navigation Tool+ for Emergency Service Delivery Optimization. IEEE Transactions on Intelligent Transportation Systems, 1-16. https://doi.org/10.1109/TITS.2017.2710881

Sung, Y. T., Chang, K. E., \& Liu, T. C. (2016). The effects of integrating mobile devices with teaching and learning on students' learning performance: A meta-analysis and research synthesis. Computers and Education, 94, 252-275. https://doi.org/10.1016/j.compedu.2015.11.008

Yavari, A. (2016). Contextualised Service Delivery in the Internet of Things, 1-6.

Ye Conghuan. (2011). Service delivery using social network analysis in P2P supportive elearning environment. Computer Science I\& Education (ICCSE), 6th International Conference, (Iccse), 411-415. https://doi.org/10.1109/ICCSE.2011.6028667

Zahiah, K., \& Abdul Razaq, A. (2010). E-Pembelajaran: Evolusi Internet Dalam Pembelajaran Sepanjang Hayat. Proceedings of Regional Conference on Knowledge Integration in ICT 2010, 209-218. https://doi.org/10.1111/eip.12107

Zanaton, H. I. (2017). Mobile learning: innovation in teaching and learning using telegram, 1(1), 19-26.

Zbick, J. (n.d.). A Web-based Reference Architecture for Mobile Learning: Its Quality Aspects and Evaluation. https://doi.org/10.1109/ICSAW.2017.8

Zhuang, R., Fang, H., Zhang, Y., Lu, A., \& Huang, R. (2017). Smart learning environments for a smart city: from the perspective of lifelong and lifewide learning. Smart Learning Environments, 4(1), 6. https://doi.org/10.1186/s40561-017-0044-8

\section{Website:}

Khaled, T. N. T. (2017). "Apakah Pendidikan Abad Ke-21", https://www.sistemguruonline.my/2017/03/pendidikan-abad-ke-21.html

Khaled, T. N. T. (2017). "Apakah Pendidikan Abad Ke-21", https://www.sistemguruonline.my/2017/03/pendidikan-abad-ke-21.html

Khaled, T. N. T. (2017). "Apakah Pendidikan Abad Ke-21", https://www.sistemguruonline.my/2017/03/pendidikan-abad-ke-21.html

Khaled, T. N. T. (2017). Apakah Pendidikan Abad Ke-21. Retrieved May 20, 2019, from https://www.sistemguruonline.my/2017/03/pendidikan-abad-ke-21.html 
Norliza, R. (2013). Penggunaan Mobile Learning (M-Learning) Untuk Tujuan Pembelajaran Dalam Kalangan Pelajar Kejuruteraan UTHM. Thesis, (Jun), 1-75. Retrieved Jan 15, 2018 from http://plato.stanford.edu/archives/win2013/entries/phenomenology/ 